\title{
ANALISIS VALIDITAS DAN RELIABILITAS TES MATA PELAJARAN PENDIDIKAN AGAMA ISLAM TINGKAT SMA
}

\author{
Zaenal Khafidin \\ STAIN Kudus, Jawa Tengah, Indonesia \\ hafidin73@yahoo.co.id
}

\begin{abstract}
Abstrak
Ujian Sekolah/madrasah sering mendapat perhatian lebih dari praktisi sebagai pentingnya pendidikan, terutama dalam 5 tahun terakhir, yaitu sejak berdirinya ujian nasional. Penelitian ini bertujuan: (1) untuk mengetahui prosedur penyusunan tes ujian akhir mata pelajaran Pendidikan Agama Islam di SMA; (2) untuk mengetahui tingkat validitas; dan (3) untuk mengetahui tingkat reliabilitas tes ujian akhir mata pelajaran Pendidikan Agama Islam di SMA. Penelitian ini menggunakan metode penelitian campuran (mixed method kualitatif-kuantitatif model Sequential Explanatory Design. Hasil penelitian ini adalah: (1) Pelaksanaan Ujian Sekolah Berstandar Nasional Mata Pelajaran Pendidikan Agama Islam (USBN-PAI) pertama kali dilaksanakan tahun pelajaran 2010/2011 berdasarkan Keputusan Direktur Jenderal Pendidikan Islam nomor: DJ.1/754/2010 tentang Pelaksanaan Ujian Sekolah Berstandar Nasional (USBN) Mata Pelajaran Pendidikan Agama Islam pada SD, SMP, SMA/SMK tahun pelajaran 2010/2011; (2) soal ujian Pendidikan Agama Islam memiliki validitas isi sebesar 99,98 \%; dan (3) nilai reliabilitas tes sebesar 0,89. Berdasarkan nilai tersebut, berarti memiliki reliabilitas sangat tinggi.
\end{abstract}

Kata kunci: validitas, reliabilitas, ujian, PAI, sekolah.

\section{Abstract}


ANALYSIS STUDY OF VALIDITY AND RELIABILITY ON ISLAMIC EDUCATION'TEST IN NATIONAL EXAMINATION OF SENIOR HIGH SCHOOL. School examination gets more attention from scientists because of the education importance, especially this last 5 years. It is since the National examination held. This research had three purposes: (1) knowing the procedure of arranging national examination test of Islamic Education subject for Senior High School;

(2) knowing the validity; and (3) knowing the reliability of the Islamic Education test. This research used mixed method (qualitative and quantitative), Sequential Explanatory Design. The results showed that: (1) national-standard school examination for Islamic Educion has been started on 2010/2011 based on the wisdom of Islamic Education General Director number: DJ.1/754/2010 about the implementation of national-standard school examination for Islamic Education subject for Elementary, Junior and Senior High School; (2) the Islamic Education test had validity 99,98\%; and (3) the Islamic Education test had reliability 0,89. It means that the test had high reliability.

Keywords: validity, reliability, examination, Islam, school.

\section{A. Pendahuluan}

Agama Islam merupakan sebuah pedoman hidup bagi umat manusia yang meliputi seluruh aspek kehidupan baik di dunia maupun di akhirat. Sebagai pedoman hidup, agama Islam memberikan bimbingan kepada umatnya tentang cara berfikir, bersikap dan bertindak dalam berhubungan dengan Tuhan, berhubungan dengan sesama manusia, dan berhubungan dengan alam raya. Sehingga terjadi kedamaian, keharmonisan dan kesejahteraan hidup di dunia maupun di akhirat. Pendidikan Agama Islam mengupayakan proses pemahaman dan internalisasi nilai-nilai ajaran Islam untuk kemudian diamalkan dalam kehidupan sehari-hari. Pendidikan Agama Islam menekankan keseimbangan, keselarasan, dan keserasian antara hubungan manusia dengan Allah SWT, hubungan manusia dengan sesama manusia, hubungan manusia dengan diri sendiri dan hubungan manusia dengan alam sekitarnya.

Kualitas Pendidikan Agama Islam sangat mempengaruhi moralitas dan karakter bangsa Indonesia. Untuk itu, perlu diadakan kajian yang mendalam dalam mengembangkan pendidikan agama Islam. Pengembangan pendidikan agama Islam tersebut meliputi 
perencanaan, proses dan hasil. Perencanaan pendidikan Agama Islam tentunya harus mempertimbangkan berbagai faktor yang mendukungnya, seperti sumber daya, konteks, dan kebutuhan peserta didik. Sedangkan proses pendidikan agama Islam mempertimbangkan berbagai metode, media dan daya penunjang lainnya. Akhirnya, hasil pendidikan agama Islam merupakan hasil ujian yang dapat dijamin standar proses, validitas dan reliabilitasnya.

Salah satu cara untuk mengetahui kualitas pendidikan agama Islam dapat diukur melalui hasil tes mata pelajaran Pendidikan Agama Islam pada ujian sekolah. Ujian sekolah/madrasah seringkali dilupakan arti pentingnya oleh para pelaksana pendidikan, terutama pada 5 tahun terakhir ini, yakni sejak ditetapkannya ujian nasional. Sebagaimana diketahui bahwa ujian sekolah/madrasah merupakan penilaian akhir untuk semua mata pelajaran pada kelompok mata pelajaran agama dan akhlak mulia, kelompok mata pelajaran kewarganegaraan dan kepribadian, kelompok mata pelajaran estetika, dan kelompok mata pelajaran jasmani, olah raga, dan kesehatan. Penilaian akhir digunakan sebagai salah satu persyaratan untuk menentukan kelulusan peserta didik dari satuan pendidikan (Diknas, 2008: 24-25).

Kriteria kelulusan sebagaimana ditegaskan dalam Peraturan Menteri Pendidikan Nasional nomor 45 tahun 2010 pasal (6) diantaranya menyatakan bahwa kelulusan peserta didik dalam ujian nasional ditentukan oleh nilai gabungan antara nilai hasil ujian sekolah dan nilai hasil ujian nasional dengan pembobotan $60 \%$ ujian nasional dan $40 \%$ ujian sekolah/madrasah. Sedangkan pada pasal (5) meneyebutkan bahwa untuk mata pelajaran yang tidak diuji secara nasional, kelulusan peserta didik ditentukan oleh nilai gabungan antara nilai rata-rata rapor semester 1,2,3,4 dan 5 dengan nilai hasil ujian sekolah/madrasah dengan pembobotan 60\% ujian sekolah/ madrasah dan $40 \%$ nilai rata-rata rapor semester 1,2,3,4 dan 5. Sebuah peran yang sangat signifikan dalam menentukan kelulusan peserta didik. Permasalahan tersebut menarik peneliti untuk melakukan penelitian ini, dimana peneliti akan mengungkap tiga hal, yaitu: (1) Bagaimana prosedur penyusunan tes ujian akhir mata pelajaran Pendidikan Agama Islam di SMA?; (2) Bagaimana tingkat validitas tes ujian akhir mata pelajaran Pendidikan Agama Islam di SMA?; 
dan (3) Bagaimana tingkat reliabilitas tes ujian akhir mata pelajaran Pendidikan Agama Islam di SMA?

Jika rumusan masalah penelitian ini ada tiga, seperti yang telah disebutkan di atas, maka tujuan penelitianpun ada tiga, yaitu: (1) untuk mengetahui prosedur penyusunan tes ujian akhir mata pelajaran Pendidikan Agama Islam di SMA; (2) untuk mengetahui tingkat validitas tes ujian akhir mata pelajaran Pendidikan Agama Islam di SMA; dan (3) untuk mengetahui tingkat reliabilitas tes ujian akhir mata pelajaran Pendidikan Agama Islam di SMA.

Hasil dari penelitian ini akan memiliki beberapa manfaat. Pertama yaitu manfaat teoretis. Secara teoretis, hasil penelitian ini diharapkan dapat memberikan gambaran pelaksanaan ujian sekolah/ madrasah khususnya mata pelajaran Pendidikan Agama Islam di SMA. Kedua yaitu manfaat praktis. Kegunaan secara praktis dari penelitian ini adalah, diharapkan dapat membantu para pendidik dalam melakukan uji validitas dan reliabilitas tes.

Penelitian ini merupakan penelitian lapangan dengan menggunakan metode penelitian campuran (mixed method kualitatif-kuantitatif model Sequential Explanatory Design sebagai mana dikemukakan oleh John W. Creswell (Creswell, 2010: 209). Pengumpulan dan analisis data kualitatif akan digunakan untuk data proses penyusunan tes. Sedangkan pengumpulan dan analisis data kuantitatif akan digunakan untuk data tingkat validitas dan reliabilitas tes. Penelitian ini dilaksanakan mulai bulan Mei sampai dengan Juni 2011 bertempat di SMA 1 Bae Kudus. Jenis data penelitian ini terdiri dari data kualitatif berupa informasi proses penyusunan tes ujian akhir mata pelajaran Pendidikan Agama Islam dan data kuantitatif berupa nilai hasil ujian akhir dan nilai ratarata raport mata pelajaran Pendidikan Agama Islam. Selanjutnya adalah instrumen pengumpulan data penelitian. Untuk data proses penyusunan tes dikumpulkan dengan menggunakan instrumen wawancara kepada pihak-pihak yang terkait dengan penyusunan tes seperti: kepala sekolah, wakil kepala sekolah bidang kurikulum dan guru Pendidikan Agama Islam. Untuk data nilai hasil ujian sekolah dan nilai raport mata pelajaran Pendidikan Agama Islam dikumpulkan dengan menggunakan metode dokumen. 
Hal yang dilakukan setelah itu adalah analisis data. Pertama, untuk data proses penyusunan tes ujian akhir mata pelajaran Pendidikan Agama Islam dianalasis dengan menggunakan pendekatan deskripitif analitis. Kedua, untuk pengujian validitas isi digunakan analisis logis kesesuaian soal dengan kisi-kisi soal. Ketiga, untuk pengujian validitas kriteria digunakan model concurrent validity dengan menghitung nilai determinasi dari nilai korelasi product moment Parson. Terakhir, untuk pengujian reliabilitas tes digunakan formula Spearman-Brown.

\section{B. Pembahasan}

\section{Prosedur Penyusunan Tes}

Prosedur penyusunan tes meliputi pengembangan indikator, pengembangan kisi-kisi, pengembangan instrumen dan penulisan butir soal.

\section{a. Pengembangan Indikator Penilaian}

Indikator penilaian dikembangkan dari setiap $\mathrm{KD}$. Indikator merupakan rumusan yang menggambarkan karakteristik, ciri-ciri, perbuatan, atau respon yang harus ditunjukkan atau dilakukan oleh peserta didik dan digunakan sebagai penanda/indikasi pencapaian kompetensi dasar. Dari setiap KD dapat dikembangkan 2 (dua atau lebih indikator penilaian dan atau indikator soal. Indikator digunakan sebagai dasar untuk menyusun instrumen penilaian. Ketercapaian indikator dapat diketahui dari perubahan perilaku peserta didik yang mencakup pengetahuan, keterampilan, dan sikap. Dalam mengembangkan Indikator, pendidik perlu menganalisis aspek dan tingkat kompetensi yang terdapat dalam kata kerja pada SK dan KD. Hal ini perlu dilakukan agar indikator yang dikembangkan dapat memenuhi kriteria sebagai penanda ketercapaian kompetensi yang diukur.

Pengembangan indikator hendaknya memperhatikan UKRK (urgensi, kontinuitas, relevansi, dan keterpakaian). Urgensi, maksudnya penting dan harus dikuasai peserta didik. Kontinuitas, yaitu pendalaman dan/atau perluasan dari kompetensi pada jenjang/ tingkat sebelumnya. Relevansi, diperlukan karena ada hubungannya untuk mempelajari atau memahami kompetensi dan/atau konsep 
mata pelajaran lain. Keterpakaian, artinya memiliki nilai terapan tinggi dalam kehidupan sehari-hari.

Syarat-syarat indikator soal yaitu: (1) menggunakan kata kerja operasional yang dapat diukur, (2) ada keterkaitan dengan materi dan kompetensi yang diuji, dan (3) dapat dibuat soalnya. Indikator soal pilihan ganda, menggunakan satu kata kerja operasional yang terukur, sedangkan untuk soal berbentuk uraian dan/atau soal praktik indikator yang dikembangkan dapat menggunakan lebih dari satu kata kerja operasional yang terukur. Indikator soal sebaiknya menggunakan stimulus (dasar pertanyaan) yang dapat berupa gambar, grafik, tabel, data hasil percobaan, atau kasus yang dapat merangsang/memotivasi peserta didik berpikir sebelum menentukan pilihan jawaban. Rumusan indikator soal yang lengkap mencakup 4 komponen, yaitu $\mathrm{A}=$ audience, $\mathrm{B}=$ behaviour, $\mathrm{C}=$ condition, dan $\mathrm{D}=$ degree (Diknas, 2008: 32)

\section{b. Pengembangan Kisi-Kisi}

Kisi-kisi merupakan format yang memuat informasi mengenai ruang lingkup dan isi/kompetensi yang akan dinilai/diujikan. Kisi-kisi disusun berdasarkan tujuan penilaian dan digunakan sebagai pedoman untuk mengembangkan soal. Kisi-kisi harus mengacu pada SK-KD dan komponen-komponennya harus rinci, jelas, dan bermakna. Kisikisi merupakan tabel matrik yang berisi spesifikasi soal-soal yang akan dibuat. Kisi-kisi ini merupakan acuan bagi penulis soal, sehingga siapapun yang menulis soal akan menghasilkan soal yang isi dan tingkat kesulitannya relatif sama. Matrik kisi-kisi soal terdiri dari dua jalur, yaitu kolom dan baris. Kolom menyatakan standar kompetensi, kompetensi dasar, materi, uraian materi dan indikator. Sedang baris menyatakan tujuan yang akan diukur atau diujikan.

Ada empat langkah dalam mengembangkan kisi-kisi tes, yaitu: 1) Menulis standar kompetensi dan kompetensi dasar; 2) Membuat materi dan uraian materi; 3) Menentukan indikator; 4) Menentukan jumlah soal pada setiap indikator (Mardapi, 2008: 90).

\section{c. Pengembangan Instrumen}

Instrumen penilaian yang dikembangkan perlu memperhatikan hal-hal berikut: 1) berhubungan dengan kondisi pembelajaran di kelas dan/atau di luar kelas; 2) relevan dengan proses pembelajaran, materi, 
kompetensi dan kegiatan pembelajaran; 3) menuntut kemampuan berpikir berjenjang, berkesinambungan, dan bermakna dengan mengacu pada aspek berpikir Taksonomi Bloom; 4) mengembangkan kemampuan berpikir kritis seperti: mendeskripsikan, menganalisis, menarik simpulan, menilai, melakukan penelitian, memecahkan masalah, dsb; 5) mengukur berbagai kemampuan yang sesuai dengan kompetensi dasar yang harus dikuasai peserta didik; 6) mengikuti kaidah penulisan soal (Diknas, 2008: 33).

\section{d. Penulisan Butir Soal}

Penulisan soal merupakan langkah menjabarkan indikator menjadi pertanyaan-pertanyaan yang karakteristiknya sesuai dengan perincian pada kisi-kisi yang telah dibuat. Langkah ini perlu dilakukan secara hati-hati agar keseluruhan tes dapat berkualitas baik. Kualitas tes secara keseluruhan sangat terpengaruh dengan tingkat kebaikan dari masing-masing butir soal yang menyusunnya. Pertanyaan perlu dikembangkan dan dibuat dengan jelas dan simpel. Soal yang tidak jelas dan terlalu bertele-tele akan menyebabkan interpretasi yang tidak tunggal dan juga membingungkan. Dengan demikian, setiap pertanyaan perlu disusun sedemikian rupa sehingga jelas yang ditanyakan dan jelas pula jawaban yang diharapkan.

Pedoman utama pembuatan tes bentuk pilihan ganda adalah:

1. Pokok soal harus jelas

2. Pilihan jawaban homogen dalam arti isi

3. Panjang kalimat pilihan jawaban relatif sama

4. Tidak ada petunjuk jawaban benar

5. Hindari menggunakan pilihan jawaban: semua benar atau semua salah

6. Pilihan jawaban angka diurutkan

7. Semua pilihan jawaban logis

8. Jangan menggunakan negatif ganda

9. Kalimat yang digunakan sesuai dengan tingkat perkembangan peserta tes

10. Bahasa yang digunakan baku

11. Letak pilihan jawaban benar ditentukan secara acak

Langkah membuat tes uraian yang mencakup objektif dan non objektif adalah sebagai berikut: 
1. Menulis soal berdasarkan indikator

2. Mengedit pertanyaan

3. Apakah pertanyaan mudah dimengerti?

4. Apakah data yang digunakan benar?

5. Apakah tata letak keseluruhan baik?

6. Apakah pemberian bobot sekor sudah tepat?

7. Apakah kunci jawaban sudah benar?

8. Apakah waktu untuk mengerjakan cukup?

Adapun kaidah penulisan soal bentuk uraian non objektif adalah sebagai berikut:

1. Gunakan kata-kata: mengapa, uraikan, jelaskan, bandingkan, tafsirkan, hitunglah, buktikan

2. Hindari penggunaan pertanyaan: siapa, apabila

3. Menggunakan bahasa baku

4. Hindari penggunaan kata-kata yang dapat ditafsirkan ganda

5. Buat petunjuk mengerjakan soal

6. Buat kunci jawaban

7. Buat pedoman pensekoran (Mardapi, 2008: 93-94).

\section{Validitas Tes}

Validits tes adalah sejauh mana tes itu mengukur apa yang dimaksudkan untuk diukur. Jadi validitas tes pada dasarnya menunjuk kepada derajat fungsi mengukurnya suatu tes. Untuk mengkaji validitas alat ukur, secara konvensional orang melihatnya dari tiga arah, yaitu: dari arah isi yang diukur, dari arah rekaan teoretis construct atribut yang diukur, dan dari arah kriteria alat ukur. Sehingga dalam sumber studi mengenai validitas tes, orang biasa membedakan validitas tes menjadi tiga macam.

Pertama adalah validitas isi. Validitas isi tes menunjuk kepada sejauh mana tes, yang merupakan seperangkat soal-soal, dilihat dari isinya memang mengukur apa yang dimaksudkan untuk diukur. Ukuran sejauhmana ini ditentukan berdasar derajat representatifnya isi tes itu bagi isi hal yang akan diukur. Validitas isi tes ditentukan melalui pendapat profesional professional judgement dalam proses telaah 
awal. Dengan menggunakan spesifi kasi tes yang telah dikembangkan telah ada orang melakukan analisis logis untuk menetapkan apakah soal-soal yang telah dikembangkan memang mengukur secara representatif bagi apa yang dimaksudkan untuk diukur. Jadi, dilihat dari kacamata validitas isi tes kegiatan telaah soal item review merupakan kegiatan yang esensial dalam pengembangan tes.

Kedua yaitu validitas konstruksi logis (construct validity). Validitas kosntruksi teoretis mempersoalkan sejauh mana skorskor hasil pengukuran dengan isntrumen yang dipersoalkan itu merefleksikan konstruksi teoretis yang mendasari penyusunan alat ukur tersebut. Validitas berdasar konstruksi teoretis ini merupakan proses yang kompleks, yang memerlukan analisis logis dan dukungan data empiris. Sampai sekarang ada dua metode yang telah diakui oleh para ahli di bidang ini, yaitu analisis faktor dan sifat jamak metode jamak (multi trait multi method).

Ketiga yaitu validitas kriteria. Validitas berdasar kriteria, alat ukur dilihat dari sejauh mana hasil pengukuran dengan alat yang dipersoalkan itu sama atau mirip dengan hasil pengukuran dengan alat lain yang dijadikan kriteria. Yang dijadikan kriteria itu biasanya hasil pengukuran atribut yang sama dengan alat lain yang diakui (dianggap merupakan alat ukur yang baik (memenuhi persyaratan akademik dan professional tertentu). Misalnya orang yang menyusun tes intelegensi mungkin menggunakan hasil pengukuran dengan tes Wechsler atau tes Santford-Binet sebagai kriteria. Validitas berdasar kriteria berdasarkan atas kapan kriteria itu dapat dimanfaatkan, dibedakan menjadi dua macam. Jika kriteria itu sekarang atau dalam waktu dekat dimanfaatkan disebut validitas sama saat (concurrent validity), dan jika kriteria itu baru beberapa waktu kemudian dimanfaatkan disebut validitas prediktif (predictive validity).

Contoh yang telah disebutkan diatas, yaitu orang menggunakan skor pada tes Weschler atau tes Standford-Binet sebagai kriteria adalah jenis validitas sama saat. Contoh validitas prediktif adalah ujian masuk perguruan tinggi yang menggunakan IPK mahasiswa sebagai kriteria. Hasil belajar mahasiswa itu baru dimiliki paling cepat setelah mahasisiwa belajar selama satu semester. Dilihat dari segi praktis maka validitas prediktif lebih penting daripada validitas sama saat, 
oleh karena setiap pengukuran pada dasarnya selalu mengandung prediksi (Suryabrata, 2005: 41-43).

\section{Reliabilitas Tes}

Reliabilitas diterjemahkan dari kata reliability. Pengukuran yang memiliki reliabilitas tinggi maksudnya adalah pengukuran yang dapat menghasilkan data yang reliabel. Reliabilitas dikenal dengan beberapa nama lain seperti keterpercayaan, keterandalan, keajegan, konsistensi, kestabilan, dan sebagainya. Ide pokok dalam konsep reliabilitas adalah sejauhmana hasil suatu pengukuran dapat dipercaya. Hasil ukur dapat dipercaya apabila dalam beberapa kali pengukuran terhadap kelompok subjek yang sama diperoleh hasil yang relatif sama, kalau aspek yang diukur dalam diri subjek memang belum berubah.

Pengertian relatif menunjukkan bahwa ada toleransi terhadap perbedaan-perbedaan kecil diantara hasil pengukuran. Bila perbedaan itu besar dari waktu ke waktu, maka hasil pengukuran itu tidak dapat dipercaya atau tidak reliabel. Reliabilitas tes dapat diestimasi melalui salah satu pendekatan umum, yaitu: pendekatan tes ulang, pendekatan tes sejajar dan pendekatan konsistensi internal (Azwar, 2007: 180). Kualitas sebuah tes dapat diketahui melalui tiga aspek, yaitu aspek kesesuaian pada standar proses penyusunan tes, tingkat validitas yang tinggi dan tingkat reliabilitas yang tinggi. Standar proses penyusunan tes meliputi pengembangan indikator, pengembangan kisi-kisi, pengembangan instrument dan penulisan butir soal. Sedangkan validitas tes meliputi validitas isi, validitas konstruk dan validitas kriteria. Dan reliabilitas tes dapat diestimasi melalui salah satu pendekatan umum, yaitu: pendekatan tes ulang, pendekatan tes sejajar dan pendekatan konsistensi internal. Kerangka berpikir ini tergambarkan dalam bagan berikut ini. 


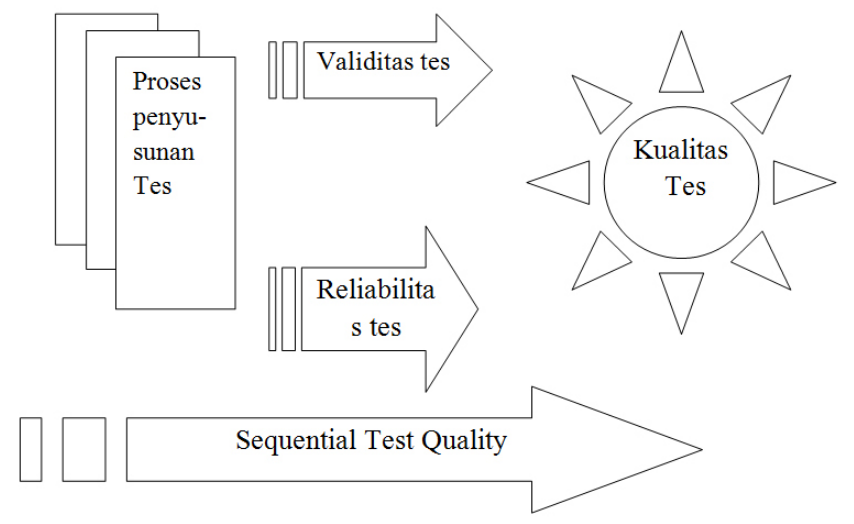

\section{Gambar 1. Kerangka Berpikir Kualitas Sebuah Tes (Validitas dan Reliabilitas)}

Berdasarkan bagan tersebut dapat dijelaskan bahwa kualitas tes dimulai dari penentuan kualitas proses penyusunan tes yang dianalisis secara kualitatif. Selanjutnya dilakukan analasis secara kuantitatif pada dua aspek, yaitu aspek validitas dan aspek reliabilitas tes. Hasil dari dua analisis tersebut kemudian dilakukan interpretasi. Hasil interpretasi tersebut menjadi tolok ukur kualitas tes.

Pelaksanaan Ujian Sekolah Berstandar Nasional Mata Pelajaran Pendidikan Agama Islam (USBN-PAIpertama kali dilaksanakan pada tahun pelajaran 2010/2011 berdasarkan Keputusan Direktur Jenderal Pendidikan Islam nomor: DJ.1/754/2010 tentang Pelaksanaan Ujian Sekolah Berstandar Nasional (USBN). Mata Pelajaran Pendidikan Agama Islam pada SD, SMP, SMA/SMK tahun pelajaran 2010/2011. USBN-PAI dilaksanakan berdasarkan pertimbangan, bahwa Pendidikan agama Islam di sekolah mempunyai peran yang strategis dalam pengembangan sistem pendidikan nasional di Indonesia dan peningkatan mutu sumber daya manusia. Oleh karenanya untuk mengetahui mutu pendidikan agama Islam yang dilaksanakan di sekolah secara nasional, maka perlu dilakukan evaluasi yang menyeluruh terhadap hasil pembelajaran peserta didik melalui Ujian Sekolah Berstandar Nasional (USBN). Selama ini pelaksanan ujian sekolah untuk mata pelajaran Pendidikan Agama Islam (PAI) sangat beragam dan tidak dapat diketahui apakah sudah memenuhi Standar Isi (SI) dan standar kompetensi lulusan (SKL) secara nasional. 
Pengujian validitas isi dalam penelitian ini dilakukan dengan membandingkan antara kisi-kisi yang sudah ditetapkan dengan butir-butir soal yang digunakan dalam USBN-PAI tahun pelajaran $2010 / 2011$. Secara umum seluruh indikator soal sudah tertuang dalam butir soal, dengan satu indikator soal dituangkan dalam satu butir soal. Namun pada indikator kedelapan yaitu Disajikan kutipan salah satu ayat tentang pengembangan IPTEK, peserta didik dapat menyimpulkan kandungan ayat tersebut, dituangkan ke dalam 3 buah butir soal yaitu butir soal nomor 8 , 9, dan 10. Sedangkan indikator soal kesembilan yaitu: ditampilkan wacana tentang pengembangan IPTEK berdasarkan QS. Yunus: 101, peserta didik dapat menentukan peran yang dapat dilakukan dalam mengembangkan IPTEK, tidak ditemukan butir soalnya. Sehingga dalam soal Ujian Sekolah Berstandar Nasional Pendidikan Agama Islam hanya satu indikator yang tidak dituangkan dalam butir soal, atau dengan kata lain USBNPAI memiliki validitas isi sebesar $99,98 \%$.

Pengujian validitas kriteria digunakan model concurrent validity dengan menghitung nilai determinasi dari nilai korelasi product moment Parson. Prosedur penghitungan validitas kriteria yang digunakan adalah sebagai berikut:

1. Membuat tabel penolong untuk menghitung nilai korelasi product moment Parson.

2. Menghitung nilai korelasi product moment Parson.

3. Menghitung nilai determinasi.

Setelah melakukan prosedur tersebut dihasilkan nilai validitas kriteria USBN-PAI dengan membandingkan dengan nilai raport semester 6 adalah sebesar 6,8\%. Berdasarkan nilai tersebut, berarti memiliki validitas kriteria sangat rendah. Hal ini dimungkinkan oleh nilai rapor semester 6. Untuk membuktikannya diperlukan uji reliabilitas tes USBN-PAI.

Pengujian reliabilitas tes USBN-PAI digunakan formula Spearman-Brown dengan menggunakan jenis penghitungan split half awal-akhir. Prosedur penghitungan tersebut adalah sebagai berikut:

1. Membuat tabel penolong untuk menghitung nilai korelasi product moment Parson.

2. Menghitung nilai korelasi product moment Parson 
Analisis Validitas dan Reliabilitas Tes Mata Pelajaran Pendidikan Agama Islam

3. Menghitung nilai reliabilitas menggunakan formula SpearmanBrown

Setelah melalui ketiga prosedur tersebut dihasilkan nilai reliabilitas USBN-PAI sebesar 0,89. Berdasarkan nilai tersebut, berarti memiliki reliabilitas sangat tinggi. Hal ini menunjukkan bahwa tes USBN-PAI memiliki konsistensi internal sangat tinggi.

\section{Simpulan}

Berdasarkan pada hasil penelitian dan analisis data dapat diambil simpulan sebagai berikut.

1. Pelaksanaan Ujian Sekolah Berstandar Nasional Mata Pelajaran Pendidikan Agama Islam (USBN-PAI) pertama kali dilaksanakan pada tahun pelajaran 2010/2011 berdasarkan Keputusan Direktur Jenderal Pendidikan Islam nomor: DJ.1/754/2010 tentang Pelaksanaan Ujian Sekolah Berstandar Nasional (USBN) Mata Pelajaran Pendidikan Agama Islam pada SD, SMP, SMA/SMK tahun pelajaran 2010/2011.

2. Model penilaian ranah afektif untuk mata pelajaran PAI yang dihasilkan memiliki nilai reliabilitas 0,76 . Hal ini menunjukkan bahwa model tersebut memiliki tingkat kendala yang tinggi.

3. Soal Ujian Sekolah Berstandar Nasional Pendidikan Agama Islam hanya satu indikator yang tidak dituangkan dalam butir soal, atau dengan kata lain USBN-PAI memiliki validitas isi sebesar $99,98 \%$.

4. Nilai reliabilitas USBN-PAI adalah sebesar 0,89. Berdasarkan nilai tersebut, berarti memiliki reliabilitas sangat tinggi. Hal ini menunjukkan bahwa tes USBN-PAI memiliki konsistensi internal sangat tinggi.

Berdasarkan pada simpulan hasil penelitian ini, dapat diberikan saran-saran sebagai berikut.

1. Para akademisi agar ikut serta dalam melalukan kalibrasi terhadap USBN PAI yang meliputi, tingkat kesulitan, daya distraktor, dan validitas item.

2. Para guru bersama-sama akademisi dapat melakukan pengujian terhadap soal-soal tes harian, mid semester dan akhir semester. 


\section{DAFTAR PUSTAKA}

Azwar, S. 2007. Sikap Manusia Teori dan Pengukurannya. Edisi 2. Yogyakarta: Pustaka Pelajar

Creswell, John W. 2010. Research Design: Qualitative, Quantitative, and Mixed Method Approaches. Third Edition. California: Sage Publication Inc.

Departemen Pendidikan Nasional. 2008. Rancangan Penilaian Hasil Belajar, Jakarta: Direktorat Pembinaan Sekolah Menengah Atas.

Mardapi, Djemari. 2008. Teknik Penyusunan Instrumen Tes dan Non Tes, Jogjakarta: Mitra Cendekia.

Peraturan Menteri Pendidikan Nasional Nomor 45 Tahun 2010 Tentang Kriteria Kelulusan Peserta Didik.

Peraturan Menteri Pendidikan Nasional Nomor 46 Tahun 2010 Tentang Pelaksanaan Ujian Sekolah/Madrasah dan Ujian Nasional.

Peraturan Pemerintah Nomor 22 tahun 2006 tentang Standar Isi Saifuddin Azwar. 2007. Tes Prestasi: Fungsi dan Pengembangan Pengukuran Prestasi Belajar, Yogyakarta: Pustaka Pelajar

Suryabrata, Sumadi. 2005. Pengembanagn Alat Ukur Psikologis. Yogyakarta: Andi Offset.

Surat Keputusan Direktur Jenderal Pendidikan Islam nomor: DJ.1/754/2010 tentang Pelaksanaan Ujian Sekolah Berstandar.

Nasional (USBN) Mata Pelajaran Pendidikan Agama Islam pada SD, SMP, SMA/SMK tahun pelajaran 2010/2011.

Tim Penyusun SMA 1 Bae Kudus. 2010. Profile SMA 1 Bae Kudus. Kudus: SMA 1 Bae Kudus. 